\title{
Pengaruh Kepuasan Kerja dan Komitmen Organisasi Terhadap Organizational Citizenship Behavior (OCB) Karyawan
}

\author{
Retty Rizda Ismaillah'1, Hendro Prasetyono² \\ 1 Unit Transfusi Darah Palang Merah Indonesia \\ 2 Universitas Indraprasta PGRI
}

\begin{tabular}{l}
\hline ARTICLE INFO \\
\hline Article History: \\
Received May $11^{\text {th }}, 2021$ \\
Revised July $2^{\text {th }}, 2021$ \\
Accepted Aug $13^{\text {th }}, 2021$
\end{tabular}

\section{Keywords:}

Kepuasan Kerja;

Komitmen Organisasi;

Organizational Citizenship

Behavior.

\begin{abstract}
Organizational Citizenship Behavior is currently a concerm of organizational leaders around the world. This study aims to determine the effect of job satisfaction and organizational commitment to Organizational Citizenship Behavior partially and simultaneously. The research method used is quantitative research with survey methods. The sampling technique is a saturated sample that uses the entire population of employees in the Blood Transfusion Unit of the Indonesian Red Cross Center of 78 people. Data collection techniques use questionnaires compiled from the development of dimensions of each variable in the study. Data analysis techniques begin with normality tests, homogeneity tests and multiple regression analysis with the help of SPSS version 23.0. The results showed that there was a positive and significant influence on job satisfaction variables on organizational citizenship behavior. Organizational Commitment variables have a positive and significant effect on Organizational Citizenship Behavior. Simultaneously, the variables of Job Satisfaction and Organizational Commitment have a positive and significant effect on Organizational Citizenship Behavior. The pathway coefficient indicates that organizational commitment contributes more than job satisfaction to Organizational Citizenship Behavior. This has implications for leaders or managers must increase employee commitment so that Organizational Citizenship Behavior increases. The limitation in this study is the research sample only from the Indonesian Red Cross in the Jakarta Branch. Further research is needed to take samples of employees from several other branches of the Indonesian Red Cross to really know the real condition
\end{abstract}

Organizational Citizenship Behavior saat ini sedang menjadi perhatian dari para pimpinan organisasi di seluruh dunia. Penelitian ini bertujuan untuk mengetahui pengaruh kepuasan kerja dan komitmen organisasi terhadap Organizational Citizenship Behavior secara parsial dan simultan. Metode penelitian yang digunakan adalah penelitian kuantitatif dengan metode survei. Teknik pengambilan sampel adalah sampel jenuh yang menggunakan seluruh populasi pegawai di Unit Transfusi Darah Pusat Palang Merah Indonesia sejumlah 78 orang. Teknik pengumpulan data menggunakan kuesioner yang disusun dari pengembangan dimensi setiap variabel dalam penelitian. Teknik analisis data diawali dengan uji normalitas, uji homogenitas, dan analisis regresi berganda dengan bantuan SPSS versi 23.0. Hasil penelitian menunjukkan bahwa terdapat pengaruh yang positif dan signifikan variabel Kepuasan Kerja terhadap Organizational Citizenship Behavior. Variabel Komitmen Organisasi berpengaruh positif dan signifikan terhadap Organizational Citizenship Behavior. Secara simultan variabel Kepuasan Kerja dan Komitmen Organisasi berpengaruh positif dan signifikan terhadap Organizational Citizenship Behavior. Koefisien jalur menunjukkan bahwa komitmen organisasi memiliki kontribusi lebih besar dibandingkan kepuasan kerja terhadap Organizational Citizenship Behavior. Hal ini berimplikasi pada pimpinan atau manajer harus meningkatkan komitmen karyawan agar Organizational Citizenship Behavior meningkat. Keterbatasan dalam penelitian ini adalah sampel penelitian hanya dari Palang Merah indonesia di Cabang DKI Jakarta. Perlu adanya penelitian lanjutan untuk mengambil sampel pegawai dari beberapa cabang Palang Merah Indonesia yang lain untuk benar-benar mengetahui kondisi sebenarnya.

\section{Corresponding Author:}

Hendro Prasetyono,

Email: hen.dro23@yahoo.com

How to Cite: Ismaillah, R.R., Prasetyono, H. (2021).Pengaruh kepuasan kerja dan komitmen organisasi terhadap organizational behavior karyawan. Sosio e-Kons, 13 (2),129-137. http://dx.doi.org/ 10.30998/sosioekons.v13i2.9749 


\section{PENDAHULUAN}

Manusia merupakan makhluk sosial yang tidak dapat hidup sendiri dalam melakukan suatu kegiatan maupun dalam usahanya mencapai suatu tujuan. Manusia membutuhkan suatu wadah yang didalamnya terdapat orang-orang dengan tujuan yang sama yang dapat diajak untuk bekerja sama, saling berkolaborasi dalam memanfaatkan sumber daya yang ada, baik dari segi materi, dana, teknologi, lingkungan, sarana, prasarana, maupun dari segi sumber daya manusia itu sendiri. Adapun wadah yang dimaksud ialah organisasi.

Barnard dalam Koton, 2019) mengemukakan bahwa organisasi itu adalah suatu sistem kegiatan-kegiatan yang terkoordinasi secara sadar atau suatu kekuatan dari dua manusia atau lebih. Potensi-potensi keuntungan bisnis yang sebelumnya tidak pernah terduga dapat dilahirkan dari sumber daya manusia, tentunya tergantung pada kualitas dan kinerja SDM itu sendiri yang tercermin pada perilaku selama di tempat kerja. Perilaku tersebut tercermin saat menjalankan tugas dan tanggung jawab maupun tidak. Berdasarkan pengalaman dan dari berbagai sumber menyebutkan biasanya ketika karyawan puas akan apa yang diperoleh dari organisasi, maka karyawan tersebut akan bekerja semaksimal mungkin sebagai bentuk timbal baliknya serta akan berupaya untuk terus memperbaiki kinerjanya dan pencapaian yang baik bagi organisasi.

Kepuasan kerja menurut Robbins dan Judge (dalam Putrana, Fathoni, \& Warso, 2016), adalah suatu perasaan positif tentang pekerjaan seseorang yang merupakan hasil dari sebuah evaluasi karakteristiknya. Perasaan tersebut akan diperlihatkan dalam bentuk perhatian dan tanggung jawabnya dalam menyelesaikan tugas yang diberikan. Perasaan positif ataupun negatif yang dialami karyawan memicu seseorang dapat mengalami kepuasan maupun ketidakpuasan kerja yang tentunya dipengaruhi dari berbagai macam elemen, diantaranya adalah pekerjaan itu sendiri, upah, promosi, supervisi, serta rekan kerja. Kepuasan kerja dapat diliat melalui hasil perbandingan antara banyaknya imbalan yang diterima dan banyaknya tugas dan tanggung jawab yang diemban. Jika imbalan yang didapat lebih banyak, maka seseorang cenderung merasa semakin puas. Sebaliknya, jika tugas dan tanggung jawab yang harus dilakukan melebihi imbalan tersebut, maka akan mengarah kepada ketidakpuasan. Ditilik dari piramida kebutuhan manusia pada teori pemenuhan kebutuhan (need fulfillment theory) kepunyaan Maslow (dalam Hikma, 2015), kepuasan kerja berada pada tingkat tertinggi yaitu kebutuhan puncak manusia yakni self-actualization needs (kebutuhan aktualisasi diri). Sebab kebutuhan individu akan aktualisasi diri dapat diartikan sebagai hasrat individu untuk memperoleh kepuasan dengan dirinya sendiri.

Dimensi kepuasan kerja dapat diukur melalui 7 (tujuh) dimensi, yaitu 1) kompensasi, baik yang bersifat langsung seperti gaji, insentif, bonus, serta tunjangan lainnya maupun yang bersifat tidak langsung seperti hak atas cuti, asuransi, berupa asuransi kesehatan dan tenaga kerja, serta fasilitas berikut dengan kebijakannya (jumlah, cara pembayaran, dan syarat perolehan); 2) pekerjaan; 3) kesempatan promosi, untuk pengembangan individu dan peningkatan jenjang karir; 4) atasan, dilihat dari gaya kepemimpinan yang dianut, termasuk di dalamnya pengakuan atas kinerja bawahannya berupa pemberian penghargaan, kepercayaan, dan kritik yang membangun; 5) rekan kerja; 6) kondisi kerja; dan 7) kebijakan organisasi, seperti kebijakan administratif dalam hal surat-menyurat, kebijakan masuk kerja di tengah pandemi, dan lain-lain ( Sugiyanto, 2016); Putrana, Fathoni, \& Warso, 2016).

Herzberg (dalam Darmawati \& Indartono, 2015) membagi faktor penyebab kepuasan dan ketidakpuasan menjadi 2 (dua) sesuai dengan teori dua faktor miliknya, yaitu Faktor motivator yang berarti karakteristik pekerjaan berkaitan dengan kepuasan pekerjaan dan Faktor hygiene yang berarti karakteristik pekerjaan berkaitan dengan ketidakpuasan pekerjaan. Tinggi rendahnya komitmen kerja seseorang juga menentukan keberhasilan manajemen di dalam organisasi. Semakin tinggi komitmen kerja seseorang, maka akan semakin besar dampak penting yang dibawa bagi kelangsungan perkembangan organisasi itu sendiri (Prasetyono, Ramdayana, \& Estiningsih, 2020).

Menurut Griffin (dalam Darmawati \& Indartono, 2015), komitmen organisasi adalah sikap yang mencerminkan sejauh mana seorang individu mengenal dan terikat pada organisasinya. Individu 
dengan komitmen yang tinggi akan melihat dirinya sebagai anggota sejati organisasi. Luthans (dalam Darmawati \& Indartono, 2015) juga berpendapat bahwa komitmen organisasi didefinisikan sebagai keinginan kuat untuk tetap sebagai anggota organisasi tertentu; keinginan untuk berusaha keras sesuai keinginan organisasi dan keyakinan tertentu; serta penerimaan nilai dan tujuan organisasi. Komitmen organisasi mencerminkan sikap positif individu pada organisasi sehingga dapat digunakan untuk memprediksi aktivitas profesional dan perilaku kerja (Prasetyono \& Ramdayana, 2020).

Allen dan Mayer (dalam Kurniawan, 2015) membagi komitmen organisasi menjadi 3 (tiga) dimensi, yaitu: Komitmen afektif (keadaan dimana karyawan ingin melakukan sesuatu untuk organisasi, komitmen berkelanjutan (keadaan dimana karyawan perlu melakukan sesuatu untuk organisasi. Hal ini mengarah pada nilai ekonomi yang dirasa dari bertahan dalam suatu organisasi bila dibandingkan dengan meninggalkan organisasi, dan komitmen normatif. Komitmen normatif juga merupakan perasaan bertanggung jawab untuk tetap tinggal dalam organisasi.

Perubahan perilaku yang disebabkan oleh kepuasan kerja dan komitmen organisasi mengarah pada baik tidaknya kinerja sumber daya manusia yang ada pada organisasi. Kinerja sumber daya manusia (karyawan) yang tinggi akan mendorong munculnya perilaku kewargaan organisasi atau OCB, yaitu perilaku melebihi apa yang telah distandarkan perusahaan (Krietner dan Kinicki, dalam Darmawati \& Indartono, 2015). Hal tersebut sesuai dengan pendapat Robbin dan Judge (dalam Darmawati \& Indartono, 2015), bahwa OCB dapat timbul dari berbagai faktor dalam organisasi, diantaranya karena adanya kepuasan kerja dari karyawan dan komitmen organisasi yang tinggi.

Keberlangsungan organisasi salah satunya dipengaruhi oleh OCB karyawannya (Lovell, dalam Darmawati \& Indartono, 2015). Jika cukup banyak karyawan yang memiliki OCB tinggi maka akan bersikap selalu membantu rekan sekerja, rela pulang lewat jam kantor jika pekerjaan belum selesai dan memiliki rasa menjadi bagian dari organisasi Beberapa penelitian tentang OCB mengungkapkan bahwa dampak dari OCB mampu meningkatkan efektivitas dan kesuksesan organisasi, sebagai contoh biaya operasional rendah, waktu penyelesaian pekerjaan lebih cepat, dan penggunaan sumber daya secara optimal. Berdasarkan peran dan manfaat OCB tersebut, manajer atau akademisi sumber daya manusia berusaha mendorong tumbuhnya OCB dalam organisasi melalui berbagai cara termasuk dengan memasukkan kriteria OCB dalam penilaian kerja (Garay, dalam Yuniar, Nurtjahjanti, \& Rusmawati, 2011).

Pendapat lain mengatakan indikator dari dimensi yang digunakan dalam variable OCB yaitu altruism atau helping behavior, courtesy atau kebaikan, conscientousness atau individual initiative, civic virtue atau organizational loyalty, dan sportmanship atau sikap sportif (Darmawati, Hidayati, \& Herlina, 2013). OCB tentu dipengaruhi oleh faktor budaya dan iklim organisasi, kepribadian dan suasana hati (mood), persepsi terhadap dukungan organisasional (perceived organizational support), persepsi terhadap kualitas hubungan atau interaksi atasan-bawahan, masa kerja, dan jenis kelamin (gender).

Organisasi yang melakukan kegiatan untuk ikut serta memberikan pelayanan masyarakat dalam bidang tertentu sebagai upaya meningkatkan taraf kehidupan dan kesejahteraan masyarakat tentu membutuhkan sumber daya manusia (karyawan) berkualitas yang dapat mensejahterakan organisasi itu sendiri. Sebagai organisasi yang melakukan pembinaan, pengawasan, pendidikan, pelatihan, rujukan, dan kegiatan lainnya terkait teknis pelayanan darah kepada UTD PMI (Unit Transfusi Darah Palang Merah Indonesia) tingkat Kota/Kabupaten dan PMI Provinsi yang berada di seluruh Indonesia, UTD PMI atau Unit Transfusi Darah Pusat PMI tentu menginginkan karyawan yang memiliki integritas dan dedikasi yang tinggi dalam melakukan pekerjaannya.

Dari pengamatan singkat yang dilakukan langsung oleh peneliti selama menjadi karyawan di UTD PMI sejak Juli 2019 sampai dengan saat ini, terdapat kekurangan dari aspek kedisiplinan dan sosial sebagai indikator dari OCB. Hal tersebut ditunjukkan dari tingkat keterlambatan karyawan saat masuk kerja yang cukup tinggi dan kurangnya komunikasi antarkaryawan secara vertikal (antara atasan dan bawahan) ataupun secara horizontal (dengan rekan kerja), baik di dalam bidang yang sama maupun antarbidang yang ada di UTDP PMI. Melihat fenomena tersebut, tentu saja akan timbul pertanyaan mengenai kepuasan kerja dan komitmen organisasi para karyawan tersebut. 
Berawal dari latar belakang di atas, peneliti tertarik untuk mengadakan penelitian yang berkaitan dengan manajemen organisasi khususnya mengenai pengaruh kepuasan kerja dan komitmen organisasi terhadap OCB Karyawan di UTD PMI baik secara parsial maupun simultan.

\section{METODE}

Penelitian ini menggunakan desain penelitian survei analitis dengan pendekatan kuantitatif karena tujuan penelitian ini adalah untuk mengetahui pengaruh kepuasan kerja dan komitmen organisasi terhadap OCB baik secara parsial maupun simultan yang dibuktikan melalui pembuktian statistik. Hipotesis yang akan diuji yaitu:

$\mathrm{H}_{1}$ : Pengaruh Kepuasan kerja $\left(\mathrm{X}_{1}\right)$ terhadap Organizational Citizenship Behavior $(\mathrm{Y})$.

$\mathrm{H}_{2}$ : Pengaruh Komitmen organisasi $\left(\mathrm{X}_{2}\right)$ terhadap Organizational Citizenship Behavior $(\mathrm{Y})$.

$\mathrm{H}_{3}$ : Pengaruh Kepuasan kerja $\left(X_{1}\right)$ dan komitmen organisasi $\left(X_{2}\right)$ secara bersama-sama terhadap Organizational Citizenship Behavior (Y).

Populasi dalam penelitian ini adalah karyawan UTD PMI sejumlah 78 orang. Metode penarikan sampel menggunakan teknik sampling jenuh, sehingga seluruh anggota populasi dijadikan sampel dalam penelitian ini.

Adapun variabel yang akan diteliti adalah kepuasan kerja dan komitmen organisasi sebagai variabel bebas (independen), dan OCB sebagai variabel terikat (dependen). Metode pengumpulan data masing-masing variabel menggunakan kuesioner tertutup yang disusun berdasarkan indikator setiap variabel. Indikator dari dimensi yang digunakan dalam variable OCB yaitu altruism atau helping behavior, courtesy atau kebaikan, conscientousness atau individual initiative, civic virtue atau organizational loyalty, dan sportmanship atau sikap sportif (Darmawati et al., 2013). Indikator dari dimensi yang digunakan dalam variabel kepuasan kerja yaitu kompensasi, pekerjaan, kesempatan promosi, atasan, rekan kerja, kondisi kerja, dan kebijakan organisasi (Belwalkar, Vohra, \& Pandey, 2018). Indikator dari dimensi yang digunakan dalam variabel komitmen organisasi yaitu komitmen afektif, komitmen berkelanjutan, dan komitmen normatif (Kim, Bonn, Lee, \& Kim, 2019). Pengukurannya dilakukan dengan pemberian skor (scoring) menggunakan skala Likert berisikan lima pilihan, yakni sangat tidak setuju $=1$, tidak setuju $=2$, netral $=3$, setuju $=4$, dan sangat setuju $=5$. Sebelum dilakukan pengambilan data dengan kuesioner yang telah disusun, terlebih dahulu dilakukan uji validitas dan reliabilitas instrumen. Teknik analisis data diawali dengan uji normalitas, uji homogenitas, analisis regresi berganda, uji hipotesis secara parsial dan simultan dengan bantuan SPSS versi 23.0.

\section{HASIL DAN PEMBAHASAN}

\section{Hasil}

Analisis data diawali dengan uji normalitas sebagai prasyarat analisis data. Hasil uji normalitas dalam penelitian ini diperoleh melalui uji Kolmogrov-Smirnov menggunakan SPSS versi 23.0 yang dapat dilihat pada tabel berikut:

Tabel 1.

Hasil Uji Normalitas

\begin{tabular}{llc}
\hline & One-Sample Kolmogorov-Smirnov Test \\
& & Unstandardized Residual \\
\hline $\mathrm{N}$ & & 78 \\
Normal Parameters & Mean &, 0000000 \\
\multirow{3}{*}{ Most Extreme Differences } & Std. Deviation & 4,74543287 \\
& Absolute &, 076 \\
& Positive &, 076 \\
& Negative &,- 049 \\
\hline
\end{tabular}




\begin{tabular}{lc}
\hline Test Statistic &, 076 \\
Asymp. Sig. (2-tailed) &, $200^{c, d}$ \\
\hline Sumber: Data diolah peneliti, (2021)
\end{tabular}

Sumber: Data diolah peneliti, (2021)

Tabel 1 di atas menunjukkan nilai signifikansi Asymp. Sig. (2-tailed) sebesar 0,200 lebih besar dari taraf signifikan (a) yakni 0,05, sehingga dapat disimpulkan bahwa data berdistribusi normal.

Selanjutnya dilanjutkan dengan uji homogenitas. Hasil uji homogenitas dalam penelitian ini diperoleh melalui uji Homogenity of Variances (Levene Statistic) menggunakan SPSS versi 23.0 yang dapat dilihat pada tabel berikut:

Tabel 2.

Hasil Uji Homogenitas

\begin{tabular}{cccc}
\hline Levene Statistic & $\mathrm{df1}$ & $\mathrm{df2}$ & Sig. \\
\hline 1,952 & 2 & 231 &, 144 \\
\hline
\end{tabular}

Sumber: Data diolah peneliti, ( 2021)

Tabel 2 di atas menunjukkan nilai signifikansi (Sig.) sebesar 0,144 lebih besar dari taraf signifikan (a) yakni 0,05, sehingga dapat disimpulkan bahwa data bersifat homogeny.

Setelah data dinyatakan berdistribusi normal dan homogen dilanjutkan dengan analisis regresi berganda untuk mengetahui besarnya koefisien jalur kontribusi variabel kepuasan kerja dan komitmen organisasi terhadap OCB. Hasilnya tersaji pada tabel berikut:

Tabel 3.

Hasil Regresi Berganda

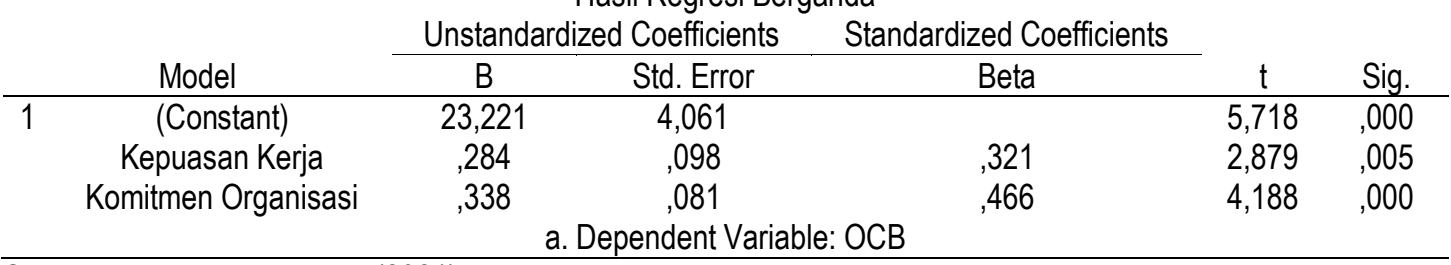

Sumber: Data diolah peneliti, (2021)

Berdasarkan hasil regresi berganda pada tabel 3 di atas, maka dapat diperoleh persamaan regresi sebagai berikut:

\section{$Y=23,221+0,284 X_{1}+0,338 X_{2}+e$}

Dari persamaan regresi berganda di atas, dapat dijelaskan sebagai berikut: Konstan memiliki nilai sebesar 23,221. Hal ini berarti jika Kepuasan Kerja $\left(X_{1}\right)$ dan Komitmen Organisasi $\left(X_{2}\right)$ bernilai 0, maka besarnya $O C B(Y)$ akan sama dengan nilai konstan yaitu sebesar 23,221. Koefesien regresi Kepuasan Kerja $\left(X_{1}\right)$ memiliki nilai sebesar 0,284 . Hal ini berarti bahwa setiap peningkatan Kepuasan Kerja $\left(X_{1}\right)$ sebesar 1, maka OCB (Y) akan mengalami peningkatan sebesar 0,284\%. Koefesien regresi Komitmen Organisasi $\left(X_{2}\right)$ memiliki nilai sebesar 0,338 . Hal ini berarti bahwa setiap peningkatan Komitmen Organisasi $\left(\mathrm{X}_{2}\right)$ sebesar 1 , maka OCB $(\mathrm{Y})$ akan mengalami peningkatan sebesar $0,338 \%$.

Langkah terakhir dalam analisis data adalah uji hipotesis yang dilakukan secara parsial maupun simultan. Perhitungan table dilakukan menggunakan tingkat signifikansi $5 \%(\alpha=0,05)$, banyaknya sampel $(n)$ yakni 78 , dan banyaknya variabel $(k)$ yakni 2 , dengan rumus berikut:

$$
\begin{aligned}
t_{\text {tabel }} & =\mathrm{t}(\mathrm{a} / 2), \text { degree of freedom }(\mathrm{df})=\mathrm{n}-\mathrm{k}-1 \\
& =\mathrm{t}(0,05 / 2),(78-2-1) \\
& =\mathrm{t}(0,025),(75) \\
& =1,9921
\end{aligned}
$$


Adapun hasil perhitungan uji t menggunakan SPSS versi 23.0 sebagai berikut:

Tabel 4.

Hasil Uji t (Uji Signifikansi Parsial)

Coefficients $^{a}$

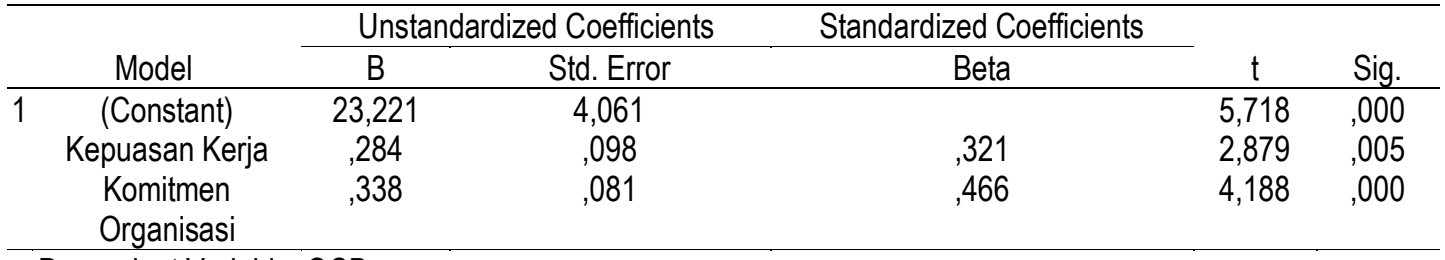

a. Dependent Variable: OCB

Sumber: Data di olah peneliti, (2021)

Berdasarkan Tabel 4 hasil Uji t (Uji Signifikansi Parsial) di atas, maka dapat diperoleh hasil sebagai berikut: Nilai $t_{\text {hitung }}$ variabel Kepuasan Kerja $\left(X_{1}\right)$ adalah sebesar 2,879 $>t_{\text {tabel }}$ 1,9921 dan nilai signifikansinya $0,005<0,05$, sehingga dapat disimpulkan bahwa Ho ditolak dan Ha diterima, yang berarti terdapat pengaruh positif antara Kepuasan Kerja $\left(\mathrm{X}_{1}\right)$ terhadap OCB $(\mathrm{Y})$ secara signifikan. Nilai $t_{\text {hitung }}$ variabel Komitmen Organisasi $\left(X_{2}\right)$ adalah sebesar 4,188 $>t_{\text {tabel }}$ 1,9921 dan nilai signifikansinya $0,000<0,05$, sehingga dapat disimpulkan bahwa Ho ditolak dan Ha diterima, yang berarti terdapat pengaruh positif antara Komitmen Organisasi $\left(\mathrm{X}_{2}\right)$ terhadap OCB $(\mathrm{Y})$ secara signifikan.

Selanjutnya dilakukan uji ketepatan model hasil penelitian menggunakan ANOVA. Perhitungan $F_{\text {table }}$ dilakukan menggunakan tingkat signifikansi $5 \%(a=0,05)$, banyaknya sampel $(n)$ yakni 78 , dan banyaknya variabel $(\mathrm{k})$ yakni 2 , dengan rumus berikut:

$$
\begin{aligned}
F_{\text {tabel }}=\mathrm{F}(\mathrm{k} ; \mathrm{n}-\mathrm{k}) & =\mathrm{F}(2 ; 78-2) \\
& =\mathrm{F}(2,76) \\
& =3,12
\end{aligned}
$$

Adapun hasil perhitungan uji F menggunakan SPSS versi 23.0 sebagai berikut:

\begin{tabular}{|c|c|c|c|c|c|c|}
\hline & & \multicolumn{5}{|c|}{ ANOVAa } \\
\hline \multicolumn{2}{|r|}{ Model } & Sum of Squares & $\mathrm{df}$ & Mean Square & $\mathrm{F}$ & Sig. \\
\hline 1 & Regression & 1956.245 & 2 & 978.122 & 42.307 & $.000 \mathrm{~b}$ \\
\hline & Residual & 1733.973 & 75 & 23.120 & & \\
\hline & Total & 3690.218 & 77 & & & \\
\hline
\end{tabular}

Tabel 5.

Hasil Uji F (Kelayakan Model)

a. Dependent Variable: OCB

b. Predictors: (Constant), Komitmen Organisasi, Kepuasan Kerja

Sumber: Data di olah peneliti, (2021)

Berdasarkan Tabel 5 Hasil Uji $F$ (Kelayakan Model) di atas, maka dapat diperoleh nilai Fhitung sebesar 42,307 > Ftabel 3,12 dan nilai signifikansi 0,000<0,05, sehingga dapat disimpulkan bahwa Ho ditolak dan Ha diterima, yang berarti terdapat pengaruh positif yang signifikan antara Kepuasan Kerja (X1) dan Komitmen Organisasi (X2) secara simultan terhadap OCB (Y). Analisis dilanjutkan dengan menghitung besarnya kontribusi variabel kepuasan kerja dan komitmen organisasi secara simultan terhadap OCB. Hasil Uji $R^{2}$ (Koefisien determinasi) tersaji pada tabel berikut:

Tabel 6.

Hasil Uji R² (Koefesien Determinasi) Model Summaryb

\begin{tabular}{lllll}
\hline Model & $R$ & R Square & Adjusted R Square & Std. Error of the Estimate \\
\hline 1 & $.728^{a}$ & .530 & .518 & 4.808 \\
\hline a. Predictors: (Constant), Komitmen Organisasi, Kepuasan Kerja \\
b. Dependent Variable: OCB \\
Sumber: Data di olah oleh peneliti
\end{tabular}


Berdasarkan hasil perhitungan uji koefesien determinasi ( $\left.R^{2}\right)$ menggunakan SPSS versi 23.0 pada tabel di atas, dapat diperoleh nilai Adjusted R Square sebesar 0,518 atau 51,8\%. Hal ini berarti Kepuasan Kerja $\left(\mathrm{X}_{1}\right)$ dan Komitmen Organisasi $\left(\mathrm{X}_{2}\right)$ dapat memengaruhi OCB $(\mathrm{Y})$ sebesar $51,8 \%$. Sedangkan sisanya yaitu sebesar $48,2 \%$ dipengaruhi oleh faktor yang tidak dijelaskan dalam penelitian ini.

\section{Pembahasan}

Hasil penelitian menunjukkan bahwa terdapat pengaruh yang positif dan signifikan antara variabel Kepuasan Kerja $\left(X_{1}\right)$ terhadap $O C B(Y)$ dilihat dari $t_{\text {hitung }}>t_{\text {tabel }}$ yaitu 2,879 $>1,9921$. Hasil ini sejalan dengan hasil penelitian lain yang menyatakan kepuasan kerja memiliki pengaruh positif dan signifikan terhadap OCB (Salehi \& Gholtash, 2011; Waspodo \& Minadaniati, 2012). Hasil koefisien jalur beta yang ditemukan pada kedua penelitian tersebut memiliki hasil yang sedikit lebih tinggi, yaitu di atas 0,40 .

Variabel Komitmen Organisasi $\left(\mathrm{X}_{2}\right)$ berpengaruh positif dan signifikan terhadap OCB $(\mathrm{Y})$ dilihat pula dari thitung $>t_{\text {tabel }}$ yaitu 4,188 $>1,9921$. Hasil ini semakin menguatkan hasil penelitian sebelumnya yang menyatakan komitmen organisasi memiliki pengaruh yang positif dan signifikan terhadap OCB (Huang, You, \& Tsai, 2012; Kurniawan, 2015). Hasil penelitian tersebut menyimpulkan bahwa baik secara parsial maupun simultan komitmen organisasi berpengaruh positif dan signifikan terhadap OCB.

Secara simultan variabel Kepuasan Kerja $\left(X_{1}\right)$ dan Komitmen Organisasi $\left(X_{2}\right)$ berpengaruh positif dan signifikan terhadap OCB $(Y)$ yang ditunjukkan oleh $F_{\text {hitung }}>F_{\text {tabel }}$ yaitu 42,307 $>3,12$. Dari semua hasil baik secara parsial maupun simultan memiliki nilai signifikansi lebih kecil dari 0,05. Persentase pengaruh kedua variabel bebas (Kepuasan Kerja dan Komitmen Organisasi) terhadap variabel terikat $(O C B)$ yaitu sebesar $51,8 \%$ dilihat dari nilai Adjusted $R$ Square sebesar 0,518. Dari hasil penelitian tersebut juga dapat disimpulkan bahwa semakin tinggi tingkat kepuasan kerja dan/atau komitmen organisasi, maka OCB yang dimiliki karyawan UTDP PMI akan turut meningkat.

Adapun hasil penelitian ini sesuai dengan penelitian yang dilakukan oleh Aswadi Lubis (2017), Yoga Putrana dkk. (2016), dan Rahayu Widayanti \& Eni Farida (2016) yang menyatakan bahwa terdapat pengaruh positif antara kepuasan kerja dan komitmen organisasi terhadap OCB. Namun hasil sedikit berbeda dari hasil penelitian milik Yoga Putrana dkk. (2016) yang dilakukan pada PT Gelora Persada Mediatama Semarang menunjukkan bahwa hanya variabel komitmen organisasi yang pengaruhnya signifikan. Temuan tersebut sangat mungkin terjadi karena perbedaan sampel penelitian dan jenis usaha dari tempat karyawan bekerja yang sangat memungkinkan hasil penelitian yang berbeda pula.

\section{SIMPULAN DAN SARAN}

Berdasarkan hasil penelitian yang dilakukan pada karyawan di UTDP PMI didapatkan hasil bahwa hipotesis akan adanya pengaruh kepuasan kerja dan komitmen organisasi terhadap OCB diterima, baik secara parsial untuk variabel Kepuasan Kerja $\left(\mathrm{X}_{1}\right)$ terhadap OCB $(\mathrm{Y})$ (thitung 2,879 $>$ tabel 1,9921), dan untuk variabel Komitmen Organisasi $\left(X_{2}\right)$ terhadap OCB $(Y)$ (thitung $4,188>t_{\text {tabel }}$ 1,9921), maupun secara simultan yang ditunjukkan oleh $F_{\text {hitung }}>F_{\text {tabel }}$ yaitu $42,307>3,12$. Dari semua hasil baik secara parsial maupun simultan memiliki nilai signifikansi lebih kecil dari 0,05 . Sehingga disimpulkan: (1) Terdapat pengaruh kepuasan kerja terhadap $O C B$ secara positif dan signifikan pada karyawan UTDP PMI; (2) Terdapat pengaruh komitmen organisasi terhadap OCB secara positif dan signifikan pada karyawan UTDP PMI; (3) Terdapat pengaruh kepuasan kerja dan komitmen organisasi terhadap OCB secara positif dan signifikan pada karyawan UTDP PMI. Koefisien jalur menunjukkan bahwa komitmen organisasi memiliki kontribusi lebih besar dibandingkan kepuasan kerja terhadap Organizational Citizenship Behavior. Hal ini berimplikasi pada pimpinan atau manajer harus 
meningkatkan komitmen karyawan agar Organizational Citizenship Behavior meningkat. Keterbatasan dalam penelitian ini adalah sampel penelitian hanya dari Palang Merah Indonesia di Cabang DKI Jakarta. Perlu adanya penelitian lanjutan untuk mengambil sampel pegawai dari beberapa cabang Palang Merah Indonesia yang lain untuk benar-benar mengetahui kondisi sebenarnya.

\section{REFERENCES/DAFTAR PUSTAKA}

Akbar, A., Al-Musadieq, M., \& Mukzam, M. D. (2017). Pengaruh Komitmen Organisasional terhadap Kinerja Karyawan PT PELINDO Surabaya. Jurnal Administrasi Bisnis (JAB), 47(2), 33-38.

Belwalkar, S., Vohra, V., \& Pandey, A. (2018). The relationship between workplace spirituality, job satisfaction and organizational citizenship behaviors: an empirical study. Social Responsibility Journal, 14(2), 410-430. https://doi.org/10.1108/SRJ-05-2016-0096

Darmawati, A., Hidayati, L. N., \& Herlina, D. (2013). Pengaruh Kepuasan Kerja Dan Komitmen Organisasi Terhadap Organizational Citizenship Behavior. Jurnal Economia, 9(1), 10-17.

Darmawati, A., \& Indartono, S. (2015). Pengaruh Kepuasan Kerja terhadap Organizational Citizenship Behavior dengan Komitmen Organisasi sebagai Variabel Mediasi. Jurnal IImu Manajemen, 12(2), 49-64

Hikma, N. (2015). Aspek Psikologis Tokoh Utama dalam Novel Sepatu Dahlan Karya Khrisna Pabichara (Kajian Psikologi Humanistik Abraham Maslow). Jurnal Humanika, 3(15), 1-15.

Huang, C. C., You, C. S., \& Tsai, M. T. (2012). A Multidimensional Analysis Of Ethical Climate, Job Satisfaction, Organizational Commitment, And Organizational Citizenship Behaviors. Nursing Ethics, 19(4), 513-529. https://doi.org/10.1177/0969733011433923

Kim, M. J., Bonn, M., Lee, C. K., \& Kim, J. S. (2019). Effects of employees' personality and attachment on job flow experience relevant to organizational commitment and consumer-oriented behavior. Journal of Hospitality and Tourism Management, 41(August), 156-170. https://doi.org/10.1016/j.jhtm.2019.09.010

Koton, Y. P. (2019). Restrukturisasi Organisasi: Teori dan Aplikasi dalam Mengefektifkan Pengelolaan Keuangan Daerah. Yogyakarta: DEEPUBLISH

Kurniawan, A. (2015). Pengaruh Komitmen Organisasi Terhadap Organizational Citizenship Behavior (OCB) PT X Bandung. Jurnal Manajemen Maranatha, 15(1), 95-118.

Lubis, A. (2016). Implementasi Dimensi OCB dengan Kinerja Organisasi. el-Qanuniy, 2(1), 111-122.

Mulyaningsih. 2016. Analisis Faktor-Faktor yang Mempengaruhi Komitmen Kerja Karyawan (Studi pada Karyawan Batik Brotoseno Sragen) [skripsi]. Surakarta (ID): Universitas Muhammadiyah Surakarta

Nurhayati, D., Minarsih, M. M., \& Heru, W. S. (2016). Pengaruh Kepuasan Kerja, Lingkungan Kerja dan Loyalitas Kerja terhadap OCB pada PT Perwirabhakti Sentrasejahtera Semarang. Journal of Management, 2(2), 1-24.

Prasetyono, H., \& Ramdayana, I. P. (2020). Pengaruh servant leadership, komitmen organisasi dan lingkungan fisik terhadap kinerja guru. Jurnal Akuntabilitas Manajemen Pendidikan, 8(2), 108123. https://doi.org/10.21831/jamp.v8i2.28458

Prasetyono, H., Ramdayana, I. P., \& Estiningsih, W. (2020). Peningkatan Kinerja Guru SMK melalui Lingkungan Kerja dengan Mengoptimalkan Efektifitas Kepemimpinan dan Komitmen Tugas. Jurnal Manajemen Dan Supervisi Pendidikan, 4(3), 255-266.

Putrana, Y., Fathoni, A., \& Warso, M. M. (2016). Pengaruh Kepuasan Kerja dan Komitmen Organisasi terhadap Organizational Citizenship Behavior dalam Meningkatkan Kinerja Karyawan pada PT Gelora Persada Mediatama Semarang. Journal of Management, 2(2), 1-14.

Robbins, S. P., \& Judge, T. A. (2013). Organizational Behavior. New Jersey, United States of America: Prentice Hall. 
Salehi, M., \& Gholtash, A. (2011). The relationship between job satisfaction, job burnout and organizational commitment with the organizational citizenship behavior among members of faculty in the Islamic Azad University - first district branches, in order to provide the appropriate mode. Procedia - Social and Behavioral Sciences, 15, 306-310. https://doi.org/10.1016/j.sbspro.2011.03.091

Sefudin, A., Prasetyono, H., \& Hapsari, S. (2018). Perilaku Organisasi (Revisi ed.). Jakarta: Mitra Abadi. Soegandhi, V. M., Sutanto, E. M., \& Setiawan, R. (2013). Pengaruh Kepuasan Kerja dan Loyalitas Kerja terhadap Organizational Citizenship Behavior pada Karyawan PT Surya Timur Sakti Jatim. AGORA, 1(1), 1-12.

Sugiyanto, E. (2016). Analisis Komitmen Organisasi, Iklim Organisasi dan Kepuasan Kerja Pegawai di Sekretariat Jenderal Kementerian Agama RI. Jurnal Populis, 1(1), 19-34.

Susanti, R. (2015). Hubungan Religiusitas dan Kualitas Kehidupan Kerja dengan OCB pada Karyawan. Jurnal Psikologi, 11(2), 94-102.

Waspodo, A. A., \& Minadaniati, L. (2012). Pengaruh Kepuasan Kerja Dan Iklim Organisasi Terhadap Organizational Citizenship Behavior (OCB) Karyawan Pada PT. Trubus Swadaya. Jurnal Riset Manajemen Sains Indonesia, 3(1), 1-16.

Wijaya, C. (2017). Perilaku Organisasi. (N. S. Chaniago, Penyunt.) Medan: Lembaga Peduli Pengembangan Pendidikan Indonesia (LPPPI).

Yuniar, I. G., Nurtjahjanti, H., \& Rusmawati, D. (2011). Hubungan antara Kepuasan Kerja dan Resiliensi dengan OCB pada Karyawan Kantor Pusat PT BPD Bali. E-Journal Undip, 9(1), 1-11. 